\title{
THEORETICAL CONTEXT FOR THE HOLISTIC DIDACTIC CONCEPTS
}

\section{Zuzana Slavikova}

\section{doi: 10.18355/PG.2016.5.1.21-28}

\begin{abstract}
The ability of creative didacticism within the educational process, we want to reflect in the context of a deeper understanding of the phenomenon of creativity and integration as well as the requirements for developing and stimulating intuitions as mental function. All reflected phenomenons we understand as essential and irreplaceable ways in the arts, as well as in scientific and educational thinking. In this article we want to present their specific application options in practice for musical and pedagogical concept of Juraj Hatrík "Jewel of music".
\end{abstract}

\section{Keywords}

intuition, educational process, creativity, integration, art education

\section{Úvod}

Vedomé správanie človeka predstavuje len zlomok jeho celistvého života. Oblast' nevedomia, ktorá sa odohráva v tzv. komplexoch, dielčich psychických systémoch je staršia, hlbšia a väčšia ako vedomie. Na jednej strane ho nevedomie dopĺn̆a a na druhej strane mu protirečí. Preto je strata spojenia medzi vedome zastávaným, či vyznávaným ideálom (vonkajší svet človeka) a vnútorným psychickým stavom (vnútorný svet človeka) dôsledkom nesúrodého vývinu, ked' môže človek vnútorne zotrvávat' na archaickej, primitívnej úrovni napriek tomu, že navonok vyznáva vznešené ideály. Citlivý, tvorivý a premyslený vzt'ah k silám nevedomia, z ktorého sa rodí svet hodnôt a je tiež hlbokým zdrojom l'udskej tvorivosti, súvisí aj so zdravým individuálnym vývinom človeka. V rámci Jungovho individuačného procesu môže ignorovanie týchto obrazov existenciálnej potreby viest' k psychickým až neurotickým problémom. Súčast'ou tohto procesu je objavenie vlastnej jedinečnosti človeka, schopnost' prijatia samého seba, spoznávanie všetkých stránok svojej osobnosti a nadviazanie kontaktu s nimi.

Snaha obmedzit' životné prejavy len na to, čo je racionálne a vôl'ou kontrolovatel'né má za následok ochromenie prirodzených inštinktov l'udskej duše, prehĺbenie priepasti medzi vedomými a nevedomými zložkami.

Umelecká výchova by z nášho pohl'adu mohla pomáhat' človeku zvyšovat' vnímavost' a citlivost' pre symbolické obrazy a rozvíjat' jeho schopnost' prežívat', chápat' a tvorit' symboly, čím by stimulovala rozvoj všetkých psychických funkcií (myslenie, cítenie, zmyslové vnímanie, intuícia), no predovšetkým intuície, bez ktorej myslenie ustrnie na úrovni verbálneho 
myslenia, odtrhnutého od skutočnosti a vytratí sa schopnost' vnímat' a vidiet' analógie a súvislosti.

Nadväzujúc na roscherovské chápanie polyestetickej výchovy ako teórie, ktorej filozofia sa nazastavuje pri otázkach zmyslového vnímania, ale sústred'uje sa na otázky významu a zmyslu, chceme zamerat' väčšiu pozornost' na dôležitost' kontaktu s archetypálnymi obrazmi, štruktúrami mýtu - na ich oživovanie a aktualizáciu a na stimuláciu symbolizačných procesov v umelecko-pedagogickom edukačnom prostredí.

\section{Hudobno-pedagogický model „Drahokam hudby“}

Filozofia a koncepcia hudobno-pedagogického modelu „Drahokam hudby“ skladatel'a a pedagóga Juraja Hatríka (Hatrik, 1997), a to tak na úrovni diet'at’a ako aj budúceho učitel'a umeleckých výchov v rámci primárnej edukácie, podporuje chápanie didaktického uvažovania v intenciách teórie systémov, podl'a ktorej živé a dynamické systémy zjednocujú rôzne protikladné alebo paralelné sily do jedného účinku. Princíp plnosti a jednoty sú základné princípy, podl'a ktorých sa správajú živé organizmy. Prináša alternatívny postoj vo vzt’ahu k tradicionalistickému pedagogickému vkusu. Uprednostňuje pohl'ad z pozície požadovaného celku, kreatívnej slobody, živej skúsenosti a otvorenosti, využívania metaforiky, oživovania archetypálneho základu a symbolizačných procesov.

Prezentovaný model rieši koncepčné a metodické otázky od elementárneho stupňa po semiotickú analýzu hudobného diela na vysokoškolskom stupni. Jeho filozofia je aplikovatel'ná na všetkých stupňoch hudobnopedagogického vzdelávania. Hatrík stavia na objektívne existujúcej psychickej štruktúre človeka, snaží sa rešpektovat' komplexnost' tak na strane človeka ako aj života.

Problém tvorby pre deti u Hatríka nie je problémom redukcie kvality, hoci určitá redukcia je nevyhnutná (psychologická, ontologická a ontogenetická - postup od jednoduchých riekaniek, hádaniek k náročnejším formám, ako je rozprávka, bájka, príbeh), predsa sa však deti môžu pripravovat' na kontakt s vel'kou hudbou, s kvalitným umením.

Pri budovaní didaktického lešenia autor vychádza zo špirálovej koncepcie, kde sa od elementárnych začiatkov zaoberá tým istým na inej úrovni ontogenézy a poznania. Ontogenéza hudobného myslenia by podl'a autora mala byt' komplementárna $\mathrm{k}$ fylogenetickej skúsenosti - objavenie tonality cez pentatoniku, predtonálne l'udové piesne by malo diet'a objavovat' tak, ako to bolo objavované človekom. ${ }^{1}$

Prácu so živou hudbou reprezentuje narábanie s celkami, odkrývanie a objavovanie množstva súvislostí a úrovní oproti neživým, vypreparovaným, v praxi neexistujúcim abstrakciám - napr. oddelenie melosu od rytmu, metra, tempa, harmonickej funkčnosti, artikulácie, farby.

\footnotetext{
${ }^{1}$ Detskej schopnosti postihovat' svet v jeho prvotnej nerozlíšenej podobe - detský synkretizmus, je vlastná ikonická, obrazová štrukturácia myslenia, ktorá je prvotnejšia, fylogeneticky i ontogeneticky staršia.
} 
Za pseudodidaktický postup Hatrík považuje tiež izolovanie a preferovanie jednotlivých zložiek hudobnej výchovy - spev, inštrumentálne aktivity, pohyb, percepčné aktivity, prvky hudobnej gramotnosti, ktoré autor dopĺn̆a o polyestetické, integratívne prístupy, improvizáciu a tvorivé hry, hudobnodramatické stvárnenie hudby (od 3. ročníka) ako syntézu jednotlivých zložiek a medzipredmetové väzby. Tento model nepreferuje ani žiadne oblasti, žánre, či funkcie hudby.

Didaktizácia hudobno-teoretickej problematiky podl'a J. Hatríka (Hatrik, 1994) musí vychádzat’ z gesta a štruktúry, pretože každá hudba je súčasne gestom (reflexívnym, kontaktibilným správaním) aj štruktúrou (sofistikovaným vesmírom vzt’ahov, štruktúr, podriadených zákonitostiam života). Toto si vyžaduje, aby učitel' vopred obnažil výrazovo-existenciálne korene problematiky (emocionálna participácia), aby namodeloval zážitkovú sféru tak, aby sa spontánne, intuitívne momenty dali postupne, bez skreslenia zložitosti intelektualizovat'.

Gesto a afekt sú teda atribúty prvotnej komunikácie, prvého dotyku (čítanie „tvárí hudby“). Diet’a mladšieho školského veku fixuje obraz hudby predovšetkým ako výrazu, živého dotyku, dorozumievacieho gesta. Až na 2. stupni sa tento zážitkový a poznatkový potenciál obohatí o zážitky štruktúry a zmyslu. Stratégia ,gesto - štruktúra“ sa u mladších detí realizuje jednoducho, intuitívne, cez obrazy, analógie a metafory blízke ich veku, s postupným prenikaním do väčšej citovej a intelektuálnej híbky.

Aktivovat' gestický dialóg autor navrhuje prostredníctvom vytvárania percepčných vzoriek. Prvou etapou didaktizácie je teda afektová, emocionálna participácia a komplementácia percepčnej vzorky. Preparácia percepčnej vzorky je jednak vhl'adom do štruktúry, vytrhnutej z času, spomalenej kvôli pozorovaniu, ale aj dialógom s týmto časovým aspektom. V elementárnej hudobnej pedagogike je možné pracovat' prevažne na úrovni „sekúnd“ a „minút“, „hodiny“ sú nedostupné, až ked’ dozreje ontogenetická situácia. Silný pedagogický moment je v tom, že diet’a na pocit $\mathrm{z}$ hudby reaguje reflexívne, podvedome, mimovol'ne a vnikanie do gestiky a štruktúry sa deje cez priame aktivity, s využitím pohybu, tanca, vokálnych alebo inštrumentálnych aktivít, či kreslenia. Hatrík navrhuje pracovat' aj spriamou participáciou detí k reálnemu zneniu skladby. Využívanie komplementárnej aktivity posúva detský zážitok k radosti z podielu na niečom, čo by samo nedokázalo oživit', a čo diet'at'u dáva zážitok spolupatričnosti a užitočnosti. Ciel'om pripravených vzoriek ${ }^{2}$ hudby je vybudovat' záchytné body (ostrovčeky) živej skúsenosti, ktoré potom pri počúvaní celku posilňujú motiváciu, otvárajú dušu diet’at'a k pochopeniu zmyslu. Pri výbere percepčnej vzorky, ktorú necháva dozriet' v zážitkovom zázemí (neskôr poznatkovo fixuje), sa Hatrík riadi najmä kontrastom, polaritami, dichotómiami, hl'adaním podobností, príbuzenstiev, nuáns,

\footnotetext{
${ }^{2}$ Prostredníctvom „,percepčných vzoriek“ Hatrík rešpektuje detský „,konkretizmus“, skúsenost', ktorá ukazuje na silu detailu, koncentrovanej emocionality hudobného obrazu.
}

Slavonic Pedagogical Studies Journal, ISSN 1339-866o, Volume 5 Issue 1, February 2016 
variánt. Okolo tzv. „ostrovčekov“ živej skúsenosti sa usporadúva aj to, čo deti priamo neohmatali cez činnosti, ale kde cítia väzby, podobnosti, zmeny, odchýlky.

Detský údiv a obrazotvornost' umožňujú súčasné prijatie zázraku aj reality. Hatrík inklinuje k protikladom už samotnou podstatou svojej osobnosti, ktorá je fascinovaná detstvom, spontánnost'ou, hravost'ou a bezprostrednost'ou, s dominanciou intuitívneho vnímania sveta oproti jeho intelektuálnemu, filozofickému a híbavému založeniu. V snahe oslovit' detského poslucháča, vo svojej hudbe zo spoločného štrukturálneho jadra generuje rozličné, často navzájom protichodné „charaktery“, či „idiómy“ (diatonický prvok nahradený chromatickým, augmentácia versus diminuencia, rytmické alebo metrické zmeny), čo dosahuje cez ideu spôsobu rozvíjania motívov. Detskému poslucháčovi sa chce Hatrík priblízit' aj sémantickou ambíciou, ${ }^{3}$ ktorá sa prejavuje v tom, že jednotlivé hudobné motívy sa zasadzovaním do špecifických kontextov mnohovrstevnatého štrukturálneho tkaniva stávajú nositel'mi určitého symbolického významu (ocitnú sa v rôznom hudobnom prostredí v harmonicky statickom, alebo dynamickom kontexte, v súlade alebo rozpore s inými motívmi). Sémantický charakter má aj inštrumentácia (napr. chorál je spätý so sférou dychových nástrojov, chaos a prvopočiatok je spätý s nástrojmi orffovsko-rozprávkovej sféry a pod.).

Poznávanie a praktické zvládnutie hudobnej štruktúry sa deje využívaním elementárnej kompozície. Za improvizáciu však Hatrík považuje tvorivé hudobné myslenie, slobodný prejav invencie, tvorivý akt, ktorého výsledky presiahnu aktuálny stav zručností, návykov, vedomostí, kedy vznikne niečo nové. Schopnost' improvizovat' je treba pestovat' prostredníctvom predkreatívnych hier, kde dochádza k zoznamovaniu sa s materiálom a schémami, ich objavovaním v činnosti, hre, v narábaní s materiálom, zvukom a priestorom. Krok od fluencie, v rámci ktorej autor navrhuje kombinovat' tréning spontánnej plynulosti s tréningom adaptívnej plynulosti, s vymedzeným priestorom na pohyb, k flexibilite (na jej princípe sa rozvíja harmónia, tektonika, inštrumenácia, hudobná obrazotvornost'a pod.) považuje Hatrík za základný manéver v pedagogike hudobnej tvorivosti. Súčast'ou modelu „Drahokam hudby“ sú podnety pre elementárne inštrumentálne činnosti, v súvislosti s motivačnými podnetmi a v spojení so získavaním hudobnej gramotnosti. Od rozmanitého typu motivačných podnetov (riekanka, pieseň, percepčný preparát, skladba, rozprávka, hra a pod.) sa lúčovito do priestoru rozbiehajú jednotlivé zložky hudobnej výchovy, čím vytvárajú štruktúru „drahokamu“, ktorý otáčaním môže menit' výzor, ale stále zostáva ten istý.

V teréne hudby Hatrík navrhuje využívat' vel'mi efektívnu metódu rozvoja tvorivosti - metaforu. Návyk využívat' obrazotvornost', teda opustenie pamätového typu intelektu vedie k schopnosti simultánne nasmerovat'

3 Hatríková hudba vd’aka sémantickej ambícii nabáda k psychologickosemiotickým interpretáciám. 
úsilie viacerými smermi, čo oslobodzuje fantáziu od všeobecne známych, očakávaných a prijatel'ných stereotypov myslenia.

V intenciách pedagogickej reflexie umenia, kde nie je nič definitívne a presné, kde to „nové“ nevylučuje „staré“, poskytuje asociatívna hra, ktorá rozvetvuje do jemnej siete individuálne dojmy, zážitky a postoje (divergentný ráz myslenia), zážitok z vynachádzania a tvorenia. Prostredníctvom intuície a empatie sa tu spájajú prvky, ktoré nemajú nič spoločné, otvára sa priestor pre nové možnosti a nuansy. Synestetická metafora umožní náhlym ,vhl'adom“ objavit' híbku i podstatu nejakého významu, kam by sa nedostal racionálny postup. V hudobno-pedagogickom teréne je sila metafory schopná rozvíjat' poznanie od obrazových ekvivalentov k účinnému ovplyvňovaniu myslenia detí, ruší staré, ustálené stereotypy, všetko skostnatelé, nastol'uje dynamiku a napätie.

Didaktické uplatnenie kognitívnej metafory má svoj pandant vo fylogenetickom a ontogenetickom vývoji jazyka. Hatrík preto navrhuje obrazový ekvivalent myslenia pestovat' simultánne s abstraktným myslením (jazyk, reč). Vychádza zo skutočnosti, že metafora je akýmsi tvorivým mostom medzi pojmami (l'avá hemisféra) a obrazmi (pravá hemisféra), cvičí v prekonávaní paradoxu, otvára cestu od obrazu k pojmu a tak sa môže stat' aj mostom medzi hudobným zážitkom a hudobným pojmoslovým. ${ }^{4}$ Vel'mi cenný pre hudobnú pedagogiku je v tejto súvislosti Hatríkov apel na postupné opúšt’anie mechanistickej predstavy o štruktúre v tradičnom myslení o hudbe. Za najúčinnejší nástroj považuje metaforizáciu vzt'ahu medzi tým, čo človek pri stretnutí s hudbou prežíva, a tým, ako o nej abstraktne uvažuje, ako sa v nej racionálne orientuje. Metaforizácia hudobno-teoretickej problematiky sa darí najmä vtedy, ked' vehikulum (aktivujúca a energetizujúca zložka) metaforickej dvojice je geneticky podmienené prírodou, biomorfnými, či antropomorfnými znakmi.

Obrazy, metafory a alegórie teda majú aj svoj kognitívny potenciál, sú skryté v štruktúre nášho myslenia. Podl'a J. Hatríka (Hatrik, 2007) kognitívne relevantnú metaforizáciu je treba nasmerovat' na konotačné pole významov tak, aby bolo v čo najčistejšej väzbe na podstatu, myslené t’ažisko.

\footnotetext{
${ }^{4}$ Autor napr. tónový priestor v projekte „Jar-raj“ metaforicky vyjadril ako mandala, magický kruh, či špirála. Vo svojej praxi bohato využíva metaforickú „revíziu“ staršieho pojmoslovia, na čo nadviazala T. Pirníková (metaforizácia harmonickej kadencie T-S-D-T ako rodiny, metafora „génov“, tónov, ktoré majú akordy kadencie spoločné, a ktoré majú rôzne stupne a úrovne príbuznosti).

${ }^{5}$ Pedagogicky je podl'a Hatríka vel'mi účinná metaforika „rast zo semienka“, použitel'ná predovšetkým na preniknutie k podstate hudobnej tektoniky a formy. Nové trendy hudobnej pedagogiky prirad’ujú hudobné procesy a organizmy k živým procesom v prírode, kozme. Hudba vo svojej podstate modeluje živé procesy s rozvíjajúcim sa vnútorným organizmom. Podl’a Hatríka je účinná aj metaforizácia štrukturálnych javov v hudbe, posúvanie hraníc ustálených, všeobecne známych pojmov, ktoré sú vlastne tiež pôvodne metaforickej povahy.
}

Slavonic Pedagogical Studies Journal, ISSN 1339-8660, Volume 5 Issue 1, February 2016 
Príležitost' na silné metafory okrem problematiky tónového priestoru, stupníc, akordov, modov, ponúka aj forma, ktorú tradičné chápanie väčšinou vysvetl’uje ako skladačku z dielov, spájacích častí, oproti metaforickému chápaniu hudobnej formy ako organizmu a procesu, ktorý je chápaný ako živá cesta od všeobecného k zvláštnemu, od materiálu, ktorý patrí všetkým, k jedinečnému tvaru konkrétnej skladby, od technológie $\mathrm{k}$ estetickému prežívaniu.

Metaforické myslenie si však podl'a Hatríka vyžaduje neustále opakovanú poslucháčsku a interpretačnú skúsenost', pretože len tak vyrastie a zosilnie to, čomu V. Krupa (in Hatrik, 1997a) hovorí ,,vedomie nevyčerpatel'nosti objektu, spojené s vedomím jeho hĺbky“. Tvorba metafor preto nevyhnutne vyžaduje spoluprácu intuície, empatie a komunikačnej citlivosti.

\section{Záver}

Pri formulovaní záverov pre teóriu a prax umeleckej pedagogiky na všetkých typoch vzdelávania vychádzame z chápania kreativity v psychologickom, estetickom (umeleckom) a pedagogickom kontexte:

1. ako schopnosti otvárat' sa pre pôvodné zdroje našich skúseností (archetypy, symbolizačné procesy a pod.) a zároveň pre tvorbu nového, originálneho a aktuálneho (na úrovni diet'at'a aj budúceho učitel'a) a tomu zodpovedajúcemu výberu a tvorbe didaktických postupov fenomén kreativity je tu v úzkom prepojení na fenomén intuície;

2. zároveň ako schopnosti identifikovat' a zohl'adňovat' učebné štýly jednotlivých osobnostných typov - zmyslové verzus intuitívne typy (čo si vyžaduje iné spôsoby rozvíjania tvorivosti) a flexibilne sa pohybovat' v priestore pedagogickej stratégie a komunikácie tak, aby bol pedagóg disponovaný komplexne rozvíjat' osobnost' diet'at'a/budúceho učitel'a (všetky psychické funkcie a procesy).

Je treba umožnit' prijímat' podnety pre poznávanie $\mathrm{v}$ intenciách spôsobu vnímania, ktorý je preferenčným spôsobom diet’at'a/budúceho učitel'a, ktorým sa vzt'ahuje k svetu (dedičné predispozície).

Dôraz kladieme na rozvíjanie intuície, ako významnej zložky, či súčasti kreatívnej osobnosti, ktorá je často opomíňaná a málo stimulovaná. V praxi (aj na úrovni vysokoškolskej pedagogiky) sa stretávame s neustálym podceňovaním snahy a schopnosti prenikat' k podstate veci, odkrývat' hlbšie analógie a originálne súvislosti. Intuícia je záležitost'ou pravej mozgovej hemisféry, ktorá sa podiel'a na umeleckých procesoch, na procesoch abstrakcie, identifikácii vzt'ahov, súvislostí, prenikaní k podstate problémov. Vychádzame teda z premisy, že biologická podstata tvorivej činnosti spočíva v spolupráci obidvoch mozgových hemisfér (l'avej a pravej) a že medzi významné a požadované myšlienkové štruktúry patrí popri tak často reflektovaných tvorivých schopnostiach aj schopnost' celostného vnímania, ktoré je zamerané na celok, súvislosti a vzt'ahy.

Rozvíjanie kreativity detí mladšieho školského veku a (v priamej viazanosti $\mathrm{k}$ nim) zároveň budúcich učitel'ov umelecko-výchovných predmetov teda chápeme v súčinnosti s rozvíjaním kvality a hĺbky ich prežívania. Prehlbovanie prežívania súvisí s otvorenost'ou pre svet symbolov, archetypov, obrazného a celostného ako kódov pre komunikáciu. Zároveň 
každý tvorivý akt sa začína otvorenost'ou pre niečo nové, originálne, neočakávané a pod.

Pre kvalitu prežívaného poznania je dôležité vnímat' svet racionálne a zároveň intuitívne, teda v spolupráci s vel'kým bohatstvom sveta nevedomia a naopak - korigovat intuíciu deduktívnym myslením, vedie k výraznému obohateniu poznania a k čo najvyššej presnosti výsledku. Intuitívne myslenie je však nutné oživovat', stimulovat', trénovat'. Najprirodzenejšia sa javí cesta ponúknutia podnetov z obrazného, symbolického sveta ako „mostu“ k híbke nevedomia, s možnost'ou nazerania na problémy súčasne $\mathrm{z}$ viacerých strán (napr. metafory toho istého z rôznych umeleckých oblastí a pod.)

Ciel'om umeleckej edukácie je preto taká stimulácia, ktorá vedie k snahe stat' sa kompetentnou, autentickou, múdrou, vnútorne integrovanou a socializovanou osobnost'ou a ktorá tak na strane diet'at'a ako aj dospelého - budúceho učitel'a vedie k poznaniu zmyslu umeleckej činnosti a odkrývaniu a poznávaniu zmyslu života. $\mathrm{Na}$ tejto úrovni dochádza $\mathrm{k}$ autentickému, tvorivému vyjadreniu integrovanej osobnosti, ktorá je utváraná nielen v zmysle sebarealizácie a sebaaktualizácie, ale aj prijímania sveta hodnôt a významov.

\section{Bibliographic references}

KOKOTSAKI, D. - NEWTON, D. P. 2015. Recognizing creativity in the music classroom. In International Journal of Music Education, 33: 491-508, first published on October 16, 2015. doi: 10.1177/0255761415607081.

HATRIK, J. 1994. Didakticke aspekty integrativnych projektov v ramci predmetu Hudobna dielna na HTF VSMU. Referat na konferencii o integrativnej Hv. In Kreativita a integrativni hudebni pedagogika v europske hudebni vychove. Prague: Spolecnost pro hudebni vychovu, pp. 75-80.

HATRIK, J. 1997. Drahokam hudby. Nitra: UKF, p. 47. ISBN 80-8050141-6.

HATRIK, J. 2007. Metafora ako most medzi hudobnym zazitkom a hudobnym pojmoslovim. In Zbornik referatov zo seminarov „Pedagogicka Dvorana“. Bratislava: AUHS, H plus. ISBN 978-80-8879447-9, pp. $37-42$.

PETLAK, E. 2015. About possibilities of better preparation of future teachers. In Slavonic Pedagogical Studies Journal. The Scientific Educational Journal. Issue n2 vol.4, ISSN 1339-9055, page: 190 - 196.

PIRNIKOVA, T. 2005. Sny-Projekty-Dozrievanie. Hudobny workshop ako priestor pre integraciu. Presov: Suzvuk. ISBN 80-89188-07-9.

SALAZAR, R. - RANDLES, C. 2015. Connecting ideas to practice: The development of an undergraduate student's philosophy of music education. In International Journal of Music Education, 33: 278-289, first published on May 5, 2015 doi: 10.1177/0255761415581150.

SIMKOVA, Z. 2015. Learning styles and strategies. In Slavonic pedagogical studies journal. Vol. 4, no. 1, pp. 82-88. doi: 10.18355/PG.2015.4.1.82-88 ISSN 1339-8660.

Slavonic Pedagogical Studies Journal, ISSN 1339-866o, Volume 5 Issue 1, February 2016 
SLAVIKOVA, Z. 2008. Integrativna umelecka pedagogika. (Fragmenty) Presov: PF PU, 2008. ISBN 978-80-8068-736-6.

doc. PaedDr. Zuzana Slavíková, PhD.

Pedagogical Faculty

University of Presov

17. novembra 15, 08001 Prešov

Slovakia

zuzana.slavikova@unipo.sk 